\title{
Effects of ocean acidification on pelagic carbon fluxes in a mesocosm experiment
}

\author{
Kristian Spilling ${ }^{1,2}$, Kai G. Schulz ${ }^{3}$, Allanah J. Paul ${ }^{4}$, Tim Boxhammer ${ }^{4}$, Eric P. Achterberg ${ }^{4,5}$, Thomas Hornick ${ }^{6}$, \\ Silke Lischka ${ }^{4}$, Annegret Stuhr ${ }^{4}$, Rafael Bermúdez ${ }^{4,7}$, Jan Czerny $^{4}$, Kate Crawfurd ${ }^{8}$, Corina P. D. Brussaard ${ }^{8,9}$, \\ Hans-Peter Grossart ${ }^{6,10}$, and Ulf Riebesell ${ }^{4}$ \\ ${ }^{1}$ Marine Research Centre, Finnish Environment Institute, P.O. Box 140, 00251 Helsinki, Finland \\ ${ }^{2}$ Tvärminne Zoological Station, University of Helsinki, J. A. Palménin tie 260, 10900 Hanko, Finland \\ ${ }^{3}$ Centre for Coastal Biogeochemistry, Southern Cross University, Military Road, East Lismore, NSW 2480, Australia \\ ${ }^{4}$ GEOMAR Helmholtz Centre for Ocean Research Kiel, Düsternbrooker Weg 20, 24105 Kiel, Germany \\ ${ }^{5}$ National Oceanography Centre Southampton, European Way, University of Southampton, Southampton, SO14 3ZH, UK \\ ${ }^{6}$ Leibniz Institute of Freshwater Ecology and Inland Fisheries (IGB), Experimental Limnology, 16775 Stechlin, Germany \\ ${ }^{7}$ Facultad de Ingeniería Marítima, Ciencias Biológicas, Oceánicas y Recursos Naturales. ESPOL, \\ Escuela Superior Politécnica del Litoral, Guayaquil, Ecuador \\ ${ }^{8}$ NIOZ Royal Netherlands Institute for Sea Research, Department of Marine Microbiology and Biogeochemistry, \\ and Utrecht University, P.O. Box 59, 1790 AB Den Burg, Texel, the Netherlands \\ ${ }^{9}$ Department of Aquatic Microbiology, Institute for Biodiversity and Ecosystem Dynamics (IBED), \\ University of Amsterdam, Amsterdam, the Netherlands \\ ${ }^{10}$ Institute for Biochemistry and Biology, Potsdam University, 14469 Potsdam, Germany
}

Correspondence to: Kristian Spilling (kristian.spilling@environment.fi)

Received: 17 February 2016 - Published in Biogeosciences Discuss.: 7 March 2016

Revised: 21 September 2016 - Accepted: 22 September 2016 - Published: 4 November 2016

\begin{abstract}
About a quarter of anthropogenic $\mathrm{CO}_{2}$ emissions are currently taken up by the oceans, decreasing seawater $\mathrm{pH}$. We performed a mesocosm experiment in the Baltic Sea in order to investigate the consequences of increasing $\mathrm{CO}_{2}$ levels on pelagic carbon fluxes. A gradient of different $\mathrm{CO}_{2}$ scenarios, ranging from ambient $(\sim 370 \mu \mathrm{atm})$ to high $(\sim 1200 \mu \mathrm{atm})$, were set up in mesocosm bags $\left(\sim 55 \mathrm{~m}^{3}\right)$. We determined standing stocks and temporal changes of total particulate carbon (TPC), dissolved organic carbon (DOC), dissolved inorganic carbon (DIC), and particulate organic carbon (POC) of specific plankton groups. We also measured carbon flux via $\mathrm{CO}_{2}$ exchange with the atmosphere and sedimentation (export), and biological rate measurements of primary production, bacterial production, and total respiration. The experiment lasted for 44 days and was divided into three different phases (I: $t 0-t 16$; II: $t 17-t 30$; III: $t 31-$ t43). Pools of TPC, DOC, and DIC were approximately 420, 7200 , and $25200 \mathrm{mmol} \mathrm{C} \mathrm{m}^{-2}$ at the start of the experiment, and the initial $\mathrm{CO}_{2}$ additions increased the DIC pool by
\end{abstract}

$\sim 7 \%$ in the highest $\mathrm{CO}_{2}$ treatment. Overall, there was a decrease in TPC and increase of DOC over the course of the experiment. The decrease in TPC was lower, and increase in DOC higher, in treatments with added $\mathrm{CO}_{2}$. During phase I the estimated gross primary production (GPP) was $\sim 100 \mathrm{mmol} \mathrm{C} \mathrm{m}^{-2} \mathrm{day}^{-1}$, from which $75-95 \%$ was respired, $\sim 1 \%$ ended up in the TPC (including export), and 5-25\% was added to the DOC pool. During phase II, the respiration loss increased to $\sim 100 \%$ of GPP at the ambient $\mathrm{CO}_{2}$ concentration, whereas respiration was lower (85-95\% of GPP) in the highest $\mathrm{CO}_{2}$ treatment. Bacterial production was $\sim 30 \%$ lower, on average, at the highest $\mathrm{CO}_{2}$ concentration than in the controls during phases II and III. This resulted in a higher accumulation of DOC and lower reduction in the TPC pool in the elevated $\mathrm{CO}_{2}$ treatments at the end of phase II extending throughout phase III. The "extra" organic carbon at high $\mathrm{CO}_{2}$ remained fixed in an increasing biomass of small-sized plankton and in the DOC pool, and did not transfer into large, sinking aggregates. Our re- 
sults revealed a clear effect of increasing $\mathrm{CO}_{2}$ on the carbon budget and mineralization, in particular under nutrient limited conditions. Lower carbon loss processes (respiration and bacterial remineralization) at elevated $\mathrm{CO}_{2}$ levels resulted in higher TPC and DOC pools than ambient $\mathrm{CO}_{2}$ concentration. These results highlight the importance of addressing not only net changes in carbon standing stocks but also carbon fluxes and budgets to better disentangle the effects of ocean acidification.

\section{Introduction}

Combustion of fossil fuels and change in land use have caused increasing atmospheric concentrations of carbon dioxide $\left(\mathrm{CO}_{2}\right)$. Ca. $25 \%$ of the anthropogenic $\mathrm{CO}_{2}$ is absorbed by the oceans, thereby decreasing surface water $\mathrm{pH}$, a process termed ocean acidification (Le Quéré et al., 2009). Ocean acidification and its alterations of aquatic ecosystems have received considerable attention during the past decade, but there are many open questions, in particular related to consequences for plankton-mediated carbon fluxes.

Some studies on ocean acidification have reported increased carbon fixation (Egge et al., 2009; Engel et al., 2013), bacterial production (BP; Grossart et al., 2006), and bacterial degradation of polysaccharides (Piontek et al., 2010) at enhanced $\mathrm{CO}_{2}$ levels, with potential consequences for carbon fluxes within pelagic ecosystems and export to the deep ocean, i.e., the biological carbon pump. Increasing carbon fixation in a high- $\mathrm{CO}_{2}$ environment can translate into an enhanced sequestration of carbon (Riebesell et al., 2007), but this depends on numerous environmental factors, including phytoplankton community composition, aggregate formation, and nutrient availability. For example, if the community shifts towards smaller cell sizes and/or enhanced cycling of organic matter carbon, export from the upper water layers may decrease (Czerny et al., 2013a).

The effect of ocean acidification has mostly been studied in marine ecosystems under high phytoplankton biomass. Brackish water has lower buffering capacity than ocean water, and the $\mathrm{pH}$ fluctuates more. The limited number of studies of ocean acidification in brackish water and indications that ocean acidification effects are greatest under nutrient limitation (De Kluijver et al., 2010) motivated this mesocosm study in the Baltic Sea during low-nutrient summer months.

The Baltic Sea is functionally much like a large estuary, with a salinity gradient ranging from approximately 20 in the southwest to $<3$ in the northernmost Bothnian Bay. It is an almost-landlocked body of water with a large population in its vicinity ( $\sim 80$ million). Human activities (e.g., agriculture, shipping, and fishing) cause a number of environmental problems such as eutrophication and pollution. As a coastal sea projected to change rapidly due to interaction of direct and indirect anthropogenic pressures, the Baltic Sea can be seen as a model ecosystem for studying global change scenarios (Niiranen et al., 2013).

Most primary data from this experiment are published in several papers of this special issue (Riebesell et al., 2015). The aim of the present paper is to provide an overarching synthesis of all information related to carbon standing stocks and fluxes. This enabled us to calculate carbon budgets in relation to different $\mathrm{CO}_{2}$ levels.

\section{Materials and methods}

\subsection{Experimental setup}

Six Kiel Off-Shore Mesocosms for Ocean Simulations (KOSMOS; with a volume of ca. $55 \mathrm{~m}^{3}$ ) were moored at Storfjärden, on the south west coast of Finland $\left(59^{\circ} 51.5^{\prime} \mathrm{N}\right.$; $23^{\circ} 15.5^{\prime} \mathrm{E}$ ) on 12 June 2012 (nine KOSMOS units were originally deployed, but three were lost due to leaks). A more detailed description of the setup can be found in Paul et al. (2015). The mesocosms extended from the surface down to $19 \mathrm{~m}$ depth and had a conical bottom end, which enabled quantitative collection of the settling material. Different $\mathrm{CO}_{2}$ levels in the bags were achieved by adding filtered $(50 \mu \mathrm{m})$, $\mathrm{CO}_{2}$-saturated seawater. The $\mathrm{CO}_{2}$-enriched water was evenly distributed over the upper $17 \mathrm{~m}$ of the water columns and added in four consecutive time steps $(t 0-t 3)$. Two controls and four treatments were used, and for the controls, filtered seawater (without additional $\mathrm{CO}_{2}$ enrichment) was added. The $\mathrm{CO}_{2}$ fugacity gradient after all additions ranged from ambient (average throughout the experiment: $\sim 370 \mu \mathrm{atm}$ $f \mathrm{CO}_{2}$ ) in the two control mesocosms (M1 and M5) up to $\sim 1200 \mu \mathrm{atm} f \mathrm{CO}_{2}$ in the highest treatment (M8). We used the average $f \mathrm{CO}_{2}$ throughout this experiment $(t 1-t 43)$ to denote the different treatments: 365 (M1), 368 (M5), 497 (M7), 821 (M6), 1007 (M3), and 1231 (M8) $\mu$ atm $f \mathrm{CO}_{2}$. On $t 15$, additional $\mathrm{CO}_{2}$-saturated seawater was added to the upper $7 \mathrm{~m}$ in the same manner as the initial enrichment, to counteract outgassing of $\mathrm{CO}_{2}$.

We sampled the mesocosms every morning, but some variables were determined only every second day. Depthintegrated water samples $(0-17 \mathrm{~m})$ were taken by using integrating water samplers (IWS, HYDRO-BIOS, Kiel). The water was collected into plastic carboys $(10 \mathrm{~L})$ and transferred to the laboratory for sub-sampling and subsequent determination of carbon stocks.

\subsection{Primary variables}

For more detailed descriptions of the primary variables and the different methods used during this $\mathrm{CO}_{2}$ mesocosm campaign, we refer to other papers in this joint volume: i.e., total particulate carbon (TPC), dissolved organic carbon (DOC), and dissolved inorganic carbon (DIC) are described by Paul et al. (2015); micro- and nanophytoplankton enumeration by Bermúdez et al. (2016); picophytoplankton, heterotrophic 
prokaryotes, and viruses by Crawfurd et al. (2016); zooplankton community by Lischka et al. (2015); primary production and respiration by Spilling et al. (2016a); BP by Hornick et al. (2016); and sedimentation by Boxhammer et al. (2016) and Paul et al. (2015).

Briefly, samples for TPC $(500 \mathrm{~mL})$ were GF/F-filtered and determined using an elemental analyzer (EuroAE). DOC was measured using the high-temperature combustion method (Shimadzu TOC-VCPN) following Badr et al. (2003). DIC was determined by infrared absorption (LI-COR LI-7000 on an AIRICA system). The DIC concentrations were converted from $\mu \mathrm{mol} \mathrm{kg}{ }^{-1}$ to $\mu \mathrm{mol} \mathrm{L}^{-1}$ using the average seawater density of $1.0038 \mathrm{~kg} \mathrm{~L}^{-1}$ throughout the experiment. Settling particles were quantitatively collected every other day from sediment traps at the bottom of the mesocosm units, and the TPC was determined from the processed samples (Boxhammer et al., 2016) as described above.

Mesozooplankton was collected by net hauls $(100 \mu \mathrm{m}$ mesh size), fixed (ethanol), and counted in a stereomicroscope. Zooplankton carbon biomass (CB) was calculated using the displacement volume (DV) and the equation of Wiebe (1988): $(\log$ DV + 1.429) / 0.82 = $\log$ CB. Micro- and nanoplankton (zoo- and phytoplankton) CB was determined from microscopic counts of fixed (acidic Lugol's iodine solution) samples, and the cellular bio-volumes were determined according to Olenina et al. (2006) and converted to particulate organic carbon (POC) by the equations provided by Menden-Deuer and Lessard (2000).

Picophytoplankton were counted using flow cytometry and converted to $\mathrm{CB}$ by size fractionation (Veldhuis and Kraay, 2004) and cellular carbon conversion factors $\left(0.2 \mathrm{pg} \mathrm{C} \mu \mathrm{m}^{-3}\right.$; Waterbury et al., 1986). Prokaryotes and viruses were determined according to Marie et al. (1999) and Brussaard (2004), respectively. All heterotrophic prokaryotes, hereafter termed bacteria, and viruses were converted to $\mathrm{CB}$ assuming $12.5 \mathrm{fg} \mathrm{C}^{-1}{ }^{-1}$ (Heinänen and Kuparinen, 1991) and $0.055 \mathrm{fg} \mathrm{C}$ virus $^{-1}$ (Steward et al., 2007), respectively.

The respiration rate was calculated from the difference between the $\mathrm{O}_{2}$ concentration (measured with a Fibox 3, PreSens) before and after a $48 \mathrm{~h}$ incubation period in a dark climate-controlled room set to the average temperature observed in the mesocosms.

$\mathrm{BP}$ was determined by ${ }^{14} \mathrm{C}$-leucine $\left({ }^{14} \mathrm{C}\right.$-Leu $)$ incorporation (Simon and Azam, 1989) according to Grossart et al. (2006). The amount of incorporated ${ }^{14}$ C-Leu was converted into BP by using an intracellular isotope dilution factor of 2. A conversion factor of 0.86 was used to convert the produced protein into carbon (Simon and Azam, 1989).

Net primary production (NPP) was measured using radiolabeled $\mathrm{NaH}^{14} \mathrm{CO}_{3}$ (Steeman-Nielsen, 1952). Samples were incubated for $24 \mathrm{~h}$ in duplicate $8 \mathrm{~mL}$ vials moored on small incubation platforms at $2,4,6,8$, and $10 \mathrm{~m}$ depth next to the mesocosms. The areal primary production was calculated based on a simple linear model of the production measurements from the different depths (Spilling et al., 2016a).

\subsection{Gas exchange}

In order to calculate the $\mathrm{CO}_{2}$ gas exchange with the atmosphere $\left(\mathrm{CO}_{2 \text { flux }}\right)$, we used $\mathrm{N}_{2} \mathrm{O}$ as a tracer gas, added to mesocosm M5 and M8 (control and high $\mathrm{CO}_{2}$ treatment) according to Czerny et al. (2013b). The $\mathrm{N}_{2} \mathrm{O}$ concentration was determined every second day using gas chromatography. Using the $\mathrm{N}_{2} \mathrm{O}$ measurements, the fluxes across the water surface $\left(F_{\mathrm{N}_{2} \mathrm{O}}\right)$ were calculated according to

$F_{\mathrm{N}_{2} \mathrm{O}}=I_{t_{1}}-I_{t_{2}} /(A \times \Delta t)$,

where $I_{t_{1}}$ and $I_{t_{2}}$ are the bulk $\mathrm{N}_{2} \mathrm{O}$ concentration at time $t_{1}$ and $t_{2}$, respectively; $A$ is the surface area; and $\Delta t$ is the time difference between $t_{1}$ and $t_{2}$.

The flux velocity was then calculated by

$K_{\mathrm{N}_{2} \mathrm{O}}=F_{\mathrm{N}_{2} \mathrm{O}} /\left(C_{\mathrm{N}_{2} \mathrm{O} w}-\left(C_{\mathrm{N}_{2} \mathrm{O} \text { aw }}\right)\right)$,

where $C_{\mathrm{N}_{2} \mathrm{O}}$ is the bulk $\mathrm{N}_{2} \mathrm{O}$ concentration in the water at a given point in time and $C_{\mathrm{N}_{2}} \mathrm{O}$ aw is the equilibrium concentration for $\mathrm{N}_{2} \mathrm{O}$ (Weiss and Price, 1980).

The flux velocity for $\mathrm{CO}_{2}$ was calculated from the flux velocity of $\mathrm{N}_{2} \mathrm{O}$ according to

$k_{\mathrm{CO}_{2}}=k_{\mathrm{N}_{2} \mathrm{O}} /\left(S c_{\mathrm{CO}_{2}} / S c_{\mathrm{N}_{2} \mathrm{O}}\right)^{0.5}$,

where $S c_{\mathrm{CO}_{2}}$ and $S c_{\mathrm{N}_{2} \mathrm{O}}$ are the Schmidt numbers for $\mathrm{CO}_{2}$ and $\mathrm{N}_{2} \mathrm{O}$, respectively. The $\mathrm{CO}_{2}$ flux across the water surface was calculated according to

$F_{\mathrm{CO}_{2}}=k_{\mathrm{CO}_{2}}\left(C_{\mathrm{CO}_{2} \mathrm{w}}-C_{\mathrm{CO}_{2} \mathrm{aw}}\right)$,

where $C_{\mathrm{CO}_{2} \mathrm{w}}$ is the water concentration of $\mathrm{CO}_{2}$ and $C_{\mathrm{CO}_{2} \text { aw }}$ is the equilibrium concentration of $\mathrm{CO}_{2} \cdot \mathrm{CO}_{2}$ is preferentially taken up by phytoplankton at the surface, where also the atmospheric exchange takes place. For this reason, we used the calculated $\mathrm{CO}_{2}$ concentration (based on the integrated $\mathrm{CO}_{2}$ concentration and $\mathrm{pH}$ in the surface) from the upper $5 \mathrm{~m}$ as the input for Eq. (5).

In contrast to $\mathrm{N}_{2} \mathrm{O}$, the $\mathrm{CO}_{2}$ flux can be chemically enhanced by hydration reactions of $\mathrm{CO}_{2}$ with hydroxide ions and water molecules in the boundary layer (Wanninkhof and Knox, 1996). Using the method outlined in Czerny et al. (2013b), we found an enhancement of up to $12 \%$ on warm days, and this was included into our flux calculations.

\subsection{Data treatment}

The primary data generated in this study comprise carbon standing stock measurements of TPC, DOC, and DIC, as well as carbon estimates of meso- and microzooplankton, micro-, nano- and picophytoplankton, bacteria, and viruses. 
Flux measurements of atmospheric $\mathrm{CO}_{2}$ exchange and sedimentation of TPC as well as the biological rates of net primary production $\left(\mathrm{NPP}_{14} \mathrm{C}\right), \mathrm{BP}$, and total respiration (TR) enabled us to make carbon budget.

Based on the primary variables (chlorophyll $a(\mathrm{Chl} a)$ and temperature), the experiment where divided into three distinct phases: phase I: $t 0-t 16$; phase II: $t 17-t 30$; and phase III: $t 31-t 43$, where, e.g., Chl $a$ concentration was relatively high during phase I, decreased during phase II, and remained low during phase III (Paul et al., 2015). Measurements of pools and rates were averaged for the two first sampling points of each experimental phase $(n=2)$ and were normalized to square meters $\left(\mathrm{m}^{2}\right)$ knowing the total depth $(17 \mathrm{~m}$, excluding the sedimentation funnel) of the mesocosms. For phase III we used the average of the last two measurements as the end point $(n=2)$.

For fluxes and biological rates we used the average for the whole periods normalized to days $\left(\mathrm{day}^{-1}\right)$. The same was done for rates of change ( $\triangle \mathrm{TPC}, \triangle \mathrm{DOC}$, and $\triangle \mathrm{DIC})$, which accounted for the difference between the start and end of each phase for all carbon pools $\left(\mathrm{TPC}_{\mathrm{pool}}, \mathrm{DOC}_{\mathrm{pool}}\right.$, $\mathrm{DIC}_{\text {pool }}$ ). All error estimates were calculated as standard error (SE), and this was calculated using all measurements within each phase (e.g., calculating the $\triangle \mathrm{TPC}$ SE using the difference between each TPC measurement). The three different phases of the experiments were of different length, and each variable had a slightly different sampling regime (every 1-3 days, with some measurements missing due to technical problems). The exact sample number ( $n$ ) for each SE is presented in the Table legends 1-3. The SE for estimated rates was calculated from the square root of the sum of variance for all the variables (Eq. 5-10 below). The primary papers mentioned above (Sect. 2.2.) present detailed statistical analyses, and we only refer to those here.

NPP was measured directly, and we additionally estimated the net community production (NCP). This was done in two different ways, from the organic $\left(\mathrm{NCP}_{\mathrm{o}}\right)$ and the inorganic $\left(\mathrm{NCP}_{\mathrm{i}}\right)$ fractions of carbon. $\mathrm{NCP}_{\mathrm{o}}$ was calculated from changes in the organic fraction plus the exported TPC $\left(\mathrm{EXP}_{\mathrm{TPC}}\right)$ according to

$\mathrm{NCP}_{\mathrm{o}}=\mathrm{EXP}_{\mathrm{TPC}}+\Delta \mathrm{TPC}+\Delta \mathrm{DOC}$.

Direct measurements using ${ }^{14} \mathrm{C}$ isotope incubations should in principal provide a higher value than summing up the difference in overall carbon balance (our $\mathrm{NCP}_{\mathrm{o}}$ ), as the latter would incorporate total respiration and not only autotrophic respiration. $\mathrm{NCP}_{\mathrm{i}}$ was calculated through changes in the dissolved inorganic carbon pool, corrected for $\mathrm{CO}_{2}$ gas exchange with the atmosphere $\left(\mathrm{CO}_{2 f l u x}\right)$ according to

$\mathrm{NCP}_{\mathrm{i}}=\mathrm{CO}_{2 \text { flux }}-\Delta \mathrm{DIC}$.

In order to close the budget, we estimated GPP and DOC production $\left(\mathrm{DOC}_{\text {prod }}\right)$. GPP is defined as the photosynthetically fixed carbon without any loss processes (i.e.,
$\mathrm{NPP}+$ autotrophic respiration). GPP can be estimated based on changes in organic $\left(\mathrm{GPP}_{\mathrm{o}}\right)$ or inorganic $\left(\mathrm{GPP}_{\mathrm{i}}\right)$ carbon pools, and we used these two different approaches providing a GPP range:

$\mathrm{GPP}_{\mathrm{o}}=\mathrm{NCP}_{\mathrm{o}}+\mathrm{TR}$,

$\mathrm{GPP}_{\mathrm{i}}=\mathrm{TR}+\mathrm{CO}_{2 \text { flux }}-\Delta \mathrm{DIC}$.

During phase III, TR was not measured, and we estimated TR based on the ratios between $\mathrm{NCP}_{\mathrm{o}}$ and $\mathrm{BP}$ to TR during phase II. The minimum production of DOC ( $\mathrm{DOC}_{\operatorname{minp}}$ ) in the system was calculated assuming bacterial carbon uptake was taken from the DOC pool according to

$\mathrm{DOC}_{\text {minp }}=\Delta \mathrm{DOC}+\mathrm{BP}$.

However, this could underestimate $\mathrm{DOC}_{\text {prod }}$ as a fraction of bacterial DOC uptake is respired. Without direct measurement of (heterotrophic prokaryote) bacterial respiration (BR), we estimated BR from TR. The share of active bacteria contributing to bacterial production is typically in the range of $10-30 \%$ of the total bacterial community (Lignell et al., 2013). We used the fraction of bacterial biomass (BB) of total biomass (TB) as the maximum limit of $\mathrm{BR}(\mathrm{BR} \leq \mathrm{BB} / \mathrm{TB})$ and hence calculated max DOC production $\left(\mathrm{DOC}_{\operatorname{maxp}}\right)$ according to

$\mathrm{DOC}_{\operatorname{maxp}}=\Delta \mathrm{DOC}+\mathrm{BP}+(\mathrm{BB} \times \mathrm{TR} / \mathrm{TB})$.

We assumed that carbon synthesized by bacteria was added to the TPC pool.

There are a number of uncertainties in these calculations, but this budgeting exercise provides an order-of-magnitude estimate of the flow of carbon within the system and enables comparison between the treatments. The average of the two controls (M1 and M5) and the two highest $\mathrm{CO}_{2}$ treatments (M3 and M8) were used to illustrate $\mathrm{CO}_{2}$ effects.

\section{Results and discussion}

\subsection{Change in plankton community, from large to small forms over time}

The overall size structure of the plankton community decreased over the course of the experiment. Figure 1 illustrates the carbon content in different plankton groups in the control mesocosms. During phase I, the phytoplankton abundances increased at first in all treatments before starting to decrease at the end of phase I (Paul et al., 2015). At the start of phase II (t17), the phytoplankton biomass was higher than at the start of the experiment $\left(\sim 130 \mathrm{mmol} \mathrm{C} \mathrm{m}^{-2}\right.$ in the controls) but decreased throughout phases II and III. The fraction of picophytoplankton increased in all treatments, but some groups of picophytoplankton increased more in the high $\mathrm{CO}_{2}$ treatments (Crawfurd et al., 2016). 


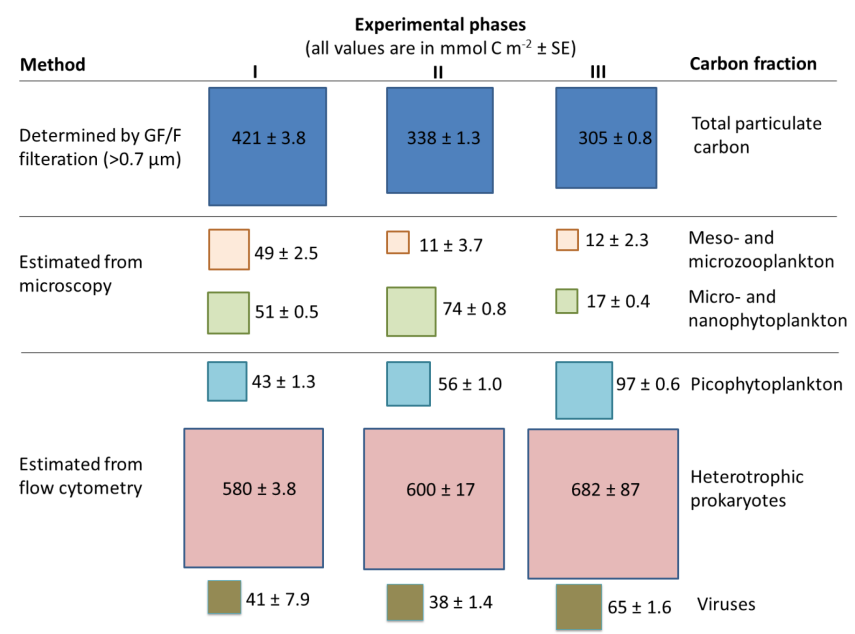

Figure 1. The different fractions of carbon in the control mesocosms (M1 and M5) at the start of phases I $(t 0)$, II ( $t 17)$, and III $(t 31)$, in mmol C m${ }^{-2} \pm \mathrm{SE}(n=2)$. The differences between the controls and elevated $\mathrm{CO}_{2}$ concentration are discussed in the text. The size of the boxes indicates the relative size of the carbon standing stocks.

Nitrogen was the limiting nutrient throughout the entire experiment (Paul et al., 2015), and primary producers are generally $\mathrm{N}$-limited in the main sub-basins of the Baltic Sea (Tamminen and Andersen, 2007). The surface-to-volume ratio increases with decreasing cell size, and consequently small cells have higher nutrient affinity and are better competitors for scarce nutrient sources than large cells (Reynolds, 2006). The prevailing $\mathrm{N}$ limitation was likely the reason for the decreasing size structure of the phytoplankton community.

Micro- and mesozooplankton standing stock was approximately half of the phytoplankton biomass initially but decreased rapidly in the control treatments during phase I (Fig. 1). In the $\mathrm{CO}_{2}$-enriched treatments, the zooplankton biomass also decreased but not to the same extent as in the control treatments (Spilling et al., 2016a). Overall, smaller species benefitted from the extra $\mathrm{CO}_{2}$ addition, but there was no significant negative effect of high $\mathrm{CO}_{2}$ on the mesozooplankton community (Lischka et al., 2015).

Bacterial biomass was the main fraction of the plankton carbon throughout the experiment. The bacterial numbers largely followed the phytoplankton biomass with an initial increase then decrease during phase I, increase during phase II, and slight decrease during phase III (Crawfurd et al., 2016). The bacterial community was controlled by mineral nutrient limitation, bacterial grazing, and viral lysis (Crawfurd et al., 2016), and bacterial growth is typically limited by $\mathrm{N}$ or a combination of $\mathrm{N}$ and $\mathrm{C}$ in the study area (Lignell et al., 2008, 2013).

The bacterial carbon pool was higher than the measured TPC. Part of the bacteria must have passed the GF/F filters
$(0.7 \mu \mathrm{m})$, and assuming pico- to mesoplankton was part of the TPC, $>50 \%$ of the bacterial carbon was not contributing to the measured TPC. The conversion factor from cells to carbon is positively correlated to cell size, and there is consequently uncertainty related to the absolute carbon content of the bacterial pool (we used a constant conversion factor). However, bacteria are known to be the dominating carbon share in the Baltic Sea during the N-limited summer months (Lignell et al., 2013), and their relative dominance is in line with this.

Although there is some uncertainty in the carbon estimate (Jover et al., 2014), viruses make up (due to their numerical dominance) a significant fraction of the pelagic carbon pool. Of the different plankton fractions the virioplankton have been the least studied, but their role in the pelagic ecosystem is ecologically important (Suttle, 2007; Brussaard et al., 2008; Mojica et al., 2016). Viral lysis rates were equivalent to the grazing rates for phytoplankton and for bacteria in the current study (Crawfurd et al., 2016). As mortality agents, viruses are key drivers of the regenerative microbial food web (Suttle, 2007; Brussaard et al., 2008). Overall, the structure of the plankton community reflected the nutrient status of the system: the increasing $\mathrm{N}$ limitation favored development of smaller cells and increased dependence of the primary producers on regenerated nutrients.

\subsection{The DIC pool and atmospheric exchange of $\mathrm{CO}_{2}$}

The DIC pool was the largest carbon pool: three-four-fold higher than the DOC pool and roughly 60 -fold higher than the TPC pool (Tables 1-3). After the addition of $\mathrm{CO}_{2}$, the DIC pool was $\sim 7 \%$ higher in the highest $\mathrm{CO}_{2}$ treatment than in the control mesocosms (Table 1). The gas exchange with the atmosphere was the most apparent flux affected by $\mathrm{CO}_{2}$ addition (Tables 1-3). Seawater in the mesocosms with added $\mathrm{CO}_{2}$ was supersaturated; hence $\mathrm{CO}_{2}$ outgassed throughout the experiment. The control mesocosms were initially undersaturated; hence ingassing occurred during phases I and II (Fig. 2). In the first part of phase III, the control mesocosms reached equilibrium with the atmospheric $f \mathrm{CO}_{2}$ (Fig. 2). The gas exchange had direct effects on the DIC concentration in the mesocosms (Fig. 3). From the measured gas exchange and change in DIC it is possible to calculate the biologically mediated carbon flux. In the mesocosms with ambient $\mathrm{CO}_{2}$ concentration, the flux measurements indicated net heterotrophy throughout the experiment. The opposite pattern, net autotrophy, was indicated in the two mesocosms with the highest $\mathrm{CO}_{2}$ addition (Fig. 3; see also Sect. 3.7.).

\subsection{The DOC pool, DOC production, and remineralization}

The DOC pool increased throughout the experiment in all mesocosm bags, albeit more in the treatments with elevated 
Table 1. The standing stock of total particulate carbon $\left(\mathrm{TPC}_{\mathrm{pool}}\right)$, dissolved organic carbon $\left(\mathrm{DOC}_{\text {pool }}\right)$, and dissolved inorganic carbon $\left(\mathrm{DIC}_{\text {pool }}\right)$ at the start of phase $\mathrm{I}$ in $\mathrm{mmol} \mathrm{C} \mathrm{m}^{-2} \pm \mathrm{SE}(n=2)$. The $\mathrm{DOC}_{\text {pool }}$ was missing some initial measurements and is the average for all mesocosms assuming that the DOC concentration was similar at the onset of the experiment. The net changes in TPC ( $\triangle \mathrm{TPC}), \mathrm{DOC}$ $(\triangle \mathrm{DOC})$, and DIC $(\triangle \mathrm{DIC})$ are average changes in the standing stocks during phase $\mathrm{I}$ in mmol $\mathrm{C}^{-2} \mathrm{day}^{-1} \pm \mathrm{SE}(n=8)$. Flux measurements of atmospheric gas exchange $\left(\mathrm{CO}_{2}\right.$ flux $)$ and exported carbon (EXP $\left.\mathrm{TPC}_{\mathrm{TP}}\right)$ plus biological rates - total respiration (TR), bacterial production (BP), and net primary production $\left(\mathrm{NPP}_{14} \mathrm{C}\right)$ - and net community production estimated based on organic carbon pools' $\left(\mathrm{NCP}_{\mathrm{O}}\right)$ net primary production are all averages for the whole of phase $\mathrm{I}$ in $\mathrm{mmol} \mathrm{C} \mathrm{m}^{-2} \mathrm{day}^{-1} \pm \mathrm{SE}\left(n=13,9,16,7\right.$, and 11 for $\mathrm{CO}_{2 f l u x}, \mathrm{EXP}_{\mathrm{TCP}}, \mathrm{TR}, \mathrm{BP}$, and $\mathrm{NPP}_{14} \mathrm{C}$, respectively). SE for $\mathrm{NCP}_{\mathrm{O}}$ was calculated from the square root of the sum of variance of the three variables used in Eq. (6). The $\mathrm{NCP}_{\mathrm{O}}$ was calculated from the net change in carbon pools plus carbon export, whereas $\mathrm{NPP}_{14} \mathrm{C}$ was measured carbon fixation using radio-labeled ${ }^{14} \mathrm{C}$ over a $24 \mathrm{~h}$ incubation period in situ. TR was measured as $\mathrm{O}_{2}$ consumption, and for comparison with carbon fixation we used a respiratory quotient (RQ) of $1 . \mathrm{CO}_{2}$ flux was only calculated for the period after full addition of $\mathrm{CO}_{2}(t 4-t 16)$. A total budget of carbon fluxes for ambient and high $\mathrm{CO}_{2}$ treatments is presented in Fig. 5.

\begin{tabular}{|c|c|c|c|c|c|c|}
\hline \multicolumn{7}{|l|}{ Phase I $(t 0-t 16)$} \\
\hline $\mathrm{CO}_{2}$ treatment $\left(\mu \mathrm{atm} f \mathrm{CO}_{2}\right)$ & 365 & 368 & 497 & 821 & 1007 & 1231 \\
\hline Mesocosm number & M1 & M5 & M7 & M6 & M3 & M8 \\
\hline $\mathrm{TPC}_{\mathrm{pool}}$ & $417 \pm 38$ & $425 \pm 39$ & $472 \pm 48$ & $458 \pm 38$ & $431 \pm 48$ & $446 \pm 57$ \\
\hline $\mathrm{DOC}_{\text {pool }}$ & $7172 \pm 87$ & $7172 \pm 87$ & $7172 \pm 87$ & $7172 \pm 87$ & $7172 \pm 87$ & $7172 \pm 87$ \\
\hline DIC pool & $25158 \pm 9$ & $25182 \pm 10$ & $25628 \pm 8$ & $26295 \pm 22$ & $26637 \pm 36$ & $26953 \pm 48$ \\
\hline$\triangle \mathrm{TPC}$ & $-4.6 \pm 15$ & $-5.2 \pm 13$ & $-8.3 \pm 13$ & $-8.2 \pm 17$ & $-7.0 \pm 13$ & $-6.3 \pm 20$ \\
\hline$\triangle \mathrm{DOC}$ & $15.5 \pm 58$ & $18.3 \pm 30$ & $18.5 \pm 33$ & $25.0 \pm 36$ & $18.5 \pm 73$ & $18.1 \pm 63$ \\
\hline$\Delta \mathrm{DIC}$ & $5.5 \pm 5.2$ & $6.9 \pm 9.2$ & $-6.1 \pm 11$ & $-24 \pm 14$ & $-32 \pm 20$ & $-49 \pm 42$ \\
\hline $\mathrm{CO}_{\text {2flux }}$ & $4.4 \pm 0.2$ & $4.8 \pm 0.3$ & $-0.8 \pm 0.5$ & $-11 \pm 1.0$ & $-17 \pm 1.4$ & $-23 \pm 2.0$ \\
\hline $\mathrm{EXP}_{\mathrm{TPC}}$ & $6.6 \pm 0.10$ & $5.6 \pm 0.04$ & $5.4 \pm 0.07$ & $6.0 \pm 0.07$ & $5.6 \pm 0.06$ & $6.0 \pm 0.05$ \\
\hline TR & $107 \pm 9$ & $82 \pm 7$ & $81 \pm 6$ & $80 \pm 8$ & $75 \pm 8$ & $74 \pm 8$ \\
\hline $\mathrm{BP}$ & $27 \pm 8$ & $41 \pm 6$ & $43 \pm 8$ & $41 \pm 4$ & $36 \pm 5$ & $46 \pm 9$ \\
\hline $\mathrm{NPP}^{14} \mathrm{C}$ & $4.8 \pm 0.8$ & $11.4 \pm 2.1$ & $14.9 \pm 3.6$ & $12.3 \pm 2.3$ & $11.3 \pm 2.4$ & $14.5 \pm 2.7$ \\
\hline $\mathrm{NCP}_{\mathrm{O}}$ & $17.4 \pm 33$ & $18.7 \pm 20$ & $15.6 \pm 30$ & $22.8 \pm 28$ & $17.1 \pm 25$ & $17.8 \pm 28$ \\
\hline
\end{tabular}

Table 2. The standing stock of total particulate carbon $\left(\mathrm{TPC}_{\mathrm{pool}}\right)$, dissolved organic carbon $\left(\mathrm{DOC}_{\text {pool }}\right)$, and dissolved inorganic carbon $\left(\mathrm{DIC}_{\text {pool }}\right)$ at the start of phase II in mmol C m ${ }^{-2} \pm \mathrm{SE}(n=2)$. The net changes in TPC $(\Delta \mathrm{TPC})$, DOC $(\Delta \mathrm{DOC})$, and DIC $(\Delta \mathrm{DIC})$ are average changes in the standing stocks during phase II in $\mathrm{mmol} \mathrm{C} \mathrm{m}{ }^{-2}$ day $^{-1} \pm \mathrm{SE}(n=7)$. Flux measurements of atmospheric gas exchange $\left(\mathrm{CO}_{2 \text { flux }}\right)$ and exported carbon $\left(\mathrm{EXP}_{\mathrm{TPC}}\right)$ plus biological rates $-\mathrm{TR}, \mathrm{BP}$, and measured $\left(\mathrm{NPP}_{14} \mathrm{C}\right)-$ and net community production estimated based on organic carbon pools $\left(\mathrm{NCP}_{\mathrm{o}}\right)$ are all averages for phase II in mmol C m${ }^{-2}$ day ${ }^{-1} \pm \mathrm{SE}\left(n=8,7,14,5\right.$, and 14 for $\mathrm{CO}_{2 f l u x}, \mathrm{EXP}_{\mathrm{TCP}}$, $\mathrm{TR}, \mathrm{BP}$, and $\mathrm{NPP}_{14} \mathrm{C}$, respectively). See Table 1 legend for further details.

\begin{tabular}{|c|c|c|c|c|c|c|}
\hline \multicolumn{7}{|l|}{ Phase II $(t 17-t 30)$} \\
\hline $\mathrm{CO}_{2}$ treatment $\left(\mu \mathrm{atm} f \mathrm{CO}_{2}\right)$ & 365 & 368 & 497 & 821 & 1007 & 1231 \\
\hline Mesocosm number & M1 & M5 & M7 & M6 & M3 & M8 \\
\hline $\mathrm{TPC}_{\text {pool }}$ & $339 \pm 14$ & $337 \pm 20$ & $331 \pm 22$ & $318 \pm 9$ & $312 \pm 12$ & $339 \pm 23$ \\
\hline DOC $_{\text {pool }}$ & $7435 \pm 38$ & $7483 \pm 37$ & $7487 \pm 43$ & $7597 \pm 37$ & $7487 \pm 61$ & $7479 \pm 37$ \\
\hline $\mathrm{DIC}_{\mathrm{pool}}$ & $25247 \pm 34$ & $25269 \pm 34$ & $25639 \pm 8$ & $26177 \pm 25$ & $26413 \pm 28$ & $26757 \pm 45$ \\
\hline$\triangle \mathrm{TPC}$ & $-2.4 \pm 5$ & $-2.3 \pm 8$ & $-1.6 \pm 14$ & $0.3 \pm 6$ & $2.8 \pm 4$ & $3.2 \pm 8$ \\
\hline$\triangle \mathrm{DOC}$ & $-0.6 \pm 39$ & $2.4 \pm 30$ & $3.6 \pm 40$ & $8.4 \pm 31$ & $11.3 \pm 58$ & $9.1 \pm 36$ \\
\hline$\Delta \mathrm{DIC}$ & $22.4 \pm 12$ & $17.6 \pm 8.1$ & $-0.4 \pm 4.5$ & $-10.5 \pm 16$ & $-14.2 \pm 10$ & $-23.1 \pm 13$ \\
\hline $\mathrm{CO}_{2 \text { flux }}$ & $1.7 \pm 0.3$ & $1.2 \pm 0.3$ & $-2.6 \pm 0.3$ & $-10 \pm 0.5$ & $-14 \pm 0.6$ & $-19 \pm 1.0$ \\
\hline $\mathrm{EXP}_{\mathrm{TPC}}$ & $3.3 \pm 0.08$ & $2.6 \pm 0.06$ & $2.5 \pm 0.08$ & $2.6 \pm 0.06$ & $2.8 \pm 0.07$ & $2.9 \pm 0.06$ \\
\hline TR & $140 \pm 7$ & $127 \pm 5$ & $103 \pm 3$ & $103 \pm 4$ & $101 \pm 5$ & $86 \pm 4$ \\
\hline $\mathrm{BP}$ & $66 \pm 17$ & $57 \pm 8$ & $61 \pm 7$ & $57 \pm 7$ & $43 \pm 6$ & $47 \pm 6$ \\
\hline $\mathrm{NPP}_{14} \mathrm{C}$ & $3.8 \pm 0.6$ & $11.2 \pm 1.9$ & $10.8 \pm 2.0$ & $14.3 \pm 2.8$ & $10.4 \pm 2.1$ & $12.0 \pm 2.5$ \\
\hline $\mathrm{NCP}_{\mathrm{o}}$ & $0.3 \pm 20$ & $2.7 \pm 15$ & $4.5 \pm 22$ & $11.4 \pm 16$ & $16.9 \pm 19$ & $15.2 \pm 16$ \\
\hline
\end{tabular}


Table 3. The standing stock of total particulate carbon $\left(\mathrm{TPC}_{\mathrm{pool}}\right)$, dissolved organic carbon ( $\left.\mathrm{DOC}_{\text {pool }}\right)$, and dissolved inorganic carbon $\left(\mathrm{DIC}_{\text {pool }}\right)$ at the start of phase III in $\mathrm{mmolC} \mathrm{m}^{-2} \pm \mathrm{SE}(n=2)$. The net change in TPC $(\Delta \mathrm{TPC})$, DOC $(\Delta \mathrm{DOC})$, and DIC $(\Delta \mathrm{DIC})$ are average changes in the standing stocks during phase III in $\mathrm{mmol} \mathrm{C} \mathrm{m}^{-2}$ day $^{-1} \pm \mathrm{SE}(n=6)$, using the average of the last two sampling days as the end point. Flux measurements of atmospheric gas exchange $\left(\mathrm{CO}_{2 \text { flux }}\right)$ and exported carbon $(\mathrm{EXP}$ TPC $)$ plus biological rates - BP and net community production estimated based on organic carbon pools $\left(\mathrm{NCP}_{\mathrm{o}}\right)-$ are all averages for phase III in $\mathrm{mmolC} \mathrm{m}^{-2} \mathrm{day}{ }^{-1} \pm \mathrm{SE}$ ( $n=7,6$, and 7 for $\mathrm{CO}_{2 \text { flux }}$, $\mathrm{EXP}_{\mathrm{TCP}}$, and $\mathrm{BP}$, respectively). See Table 1 legend for further details. During phase III we did not have direct measurements of net primary production $\left(\mathrm{NPP}_{14} \mathrm{C}\right)$ or TR.

\begin{tabular}{lrrrrrr}
\hline Phase III $(t 31-t 43)$ & & & & & & \\
$\mathrm{CO}_{2}$ treatment $\left(\mu \mathrm{atm} f \mathrm{CO}_{2}\right)$ & 365 & 368 & 497 & $\mathrm{M} 7$ & 1007 & 1231 \\
Mesocosm number & $\mathrm{M} 1$ & $\mathrm{M} 5$ & $\mathrm{M} 7$ & $\mathrm{M} 6$ & $\mathrm{M} 3$ & $\mathrm{M} 8$ \\
\hline $\mathrm{TPC}_{\text {pool }}$ & $306 \pm 12$ & $304 \pm 20$ & $309 \pm 20$ & $323 \pm 2$ & $351 \pm 13$ & $384 \pm 16$ \\
$\mathrm{DOC}_{\text {pool }}$ & $7426 \pm 16$ & $7469 \pm 20$ & $7485 \pm 92$ & $7553 \pm 20$ & $7593 \pm 30$ & $7562 \pm 38$ \\
$\mathrm{DIC}$ & $2555 \pm 9$ & $25545 \pm 10$ & $25648 \pm 13$ & $26030 \pm 19$ & $26197 \pm 31$ & $26371 \pm 32$ \\
$\Delta \mathrm{TPC}$ & $-3.8 \pm 10$ & $0.3 \pm 7$ & $3.3 \pm 14$ & $3.3 \pm 10$ & $-1.4 \pm 8$ & $-4.8 \pm 8$ \\
$\Delta \mathrm{DOC}$ & $9.8 \pm 5$ & $8.8 \pm 7$ & $8.9 \pm 43$ & $9.2 \pm 10$ & $5.7 \pm 17$ & $16.3 \pm 20$ \\
$\Delta \mathrm{DIC}$ & $4.3 \pm 3.9$ & $5.5 \pm 8.7$ & $6.2 \pm 11$ & $-12.3 \pm 7.2$ & $-16.3 \pm 14$ & $-20.1 \pm 14$ \\
$\mathrm{CO}_{2 f l u x}$ & $-0.3 \pm 0.7$ & $-0.8 \pm 0.6$ & $-3.0 \pm 0.5$ & $-7.3 \pm 0.5$ & $-9.4 \pm 0.6$ & $-13 \pm 0.6$ \\
$\mathrm{EXP}_{\text {TPC }}$ & $1.5 \pm 0.07$ & $1.4 \pm 0.05$ & $0.4 \pm 0.07$ & $1.9 \pm 0.05$ & $1.6 \pm 0.04$ & $1.7 \pm 0.05$ \\
$\mathrm{BP}_{\mathrm{NCP}}$ & $31 \pm 6.8$ & $37 \pm 1.4$ & $38 \pm 1.4$ & $27 \pm 2.1$ & $17 \pm 3.8$ & $28 \pm 2.3$ \\
& $7.6 \pm 16$ & $10.5 \pm 13$ & $12.7 \pm 20$ & $14.3 \pm 13$ & $6.0 \pm 10$ & $13.2 \pm 14$
\end{tabular}

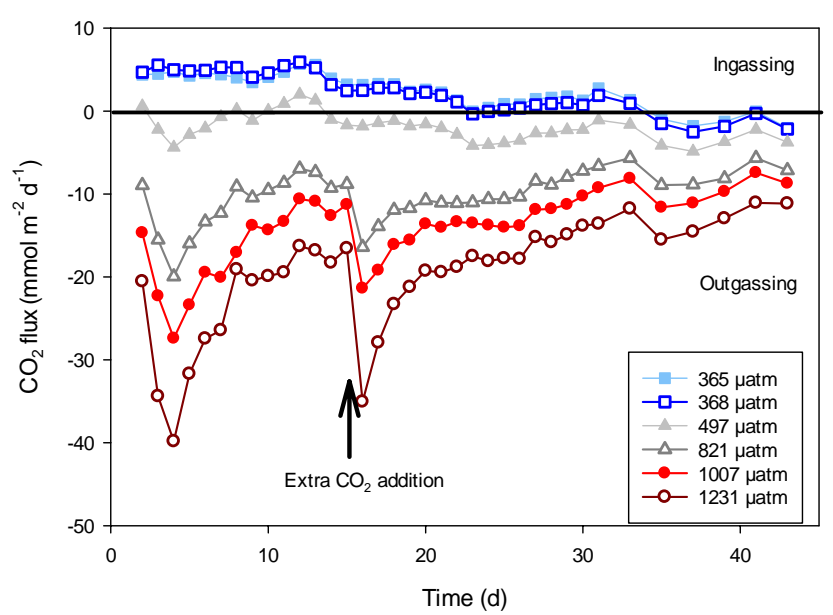

Figure 2. The calculated exchange of $\mathrm{CO}_{2}$ between the mesocosms and the atmosphere. Positive values indicate net influx (ingassing), and negative values net outflux (outgassing) from the mesocosms. The flux was based on measurements of $\mathrm{N}_{2} \mathrm{O}$ as a tracer gas and calculated using Eqs. (2)-(5).

$\mathrm{CO}_{2}$ concentration. The initial DOC standing stock in all treatments was approximately $7200 \mathrm{mmol} \mathrm{C} \mathrm{m}^{-2}$. At the end of the experiment, the DOC pool was $\sim 2 \%$ higher in the two highest $\mathrm{CO}_{2}$ treatments than in the controls (Fig. 4), and there is statistical support for this difference between $\mathrm{CO}_{2}$ treatments (phase III, $p=0.05$ ) (Paul et al., 2015). Interestingly, the data do not point to a substantially higher release of DOC at high $\mathrm{CO}_{2}$ (Figs. 4 and 5). The bacterial production was notably lower during phase II in the high $\mathrm{CO}_{2}$ treatments (Hornick et al., 2016) and of similar magnitude to the rate

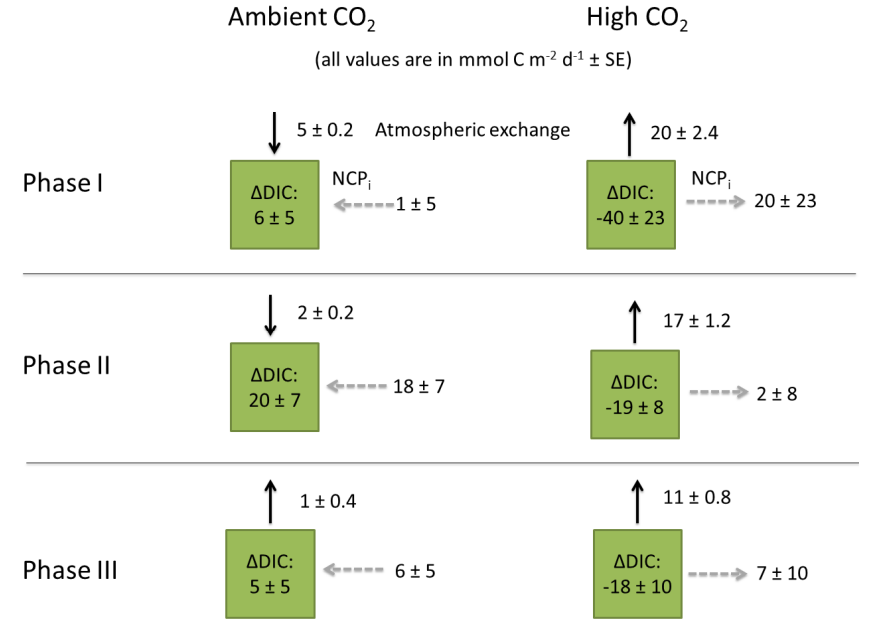

Figure 3. Change in DIC pool and the atmospheric $\mathrm{CO}_{2}$ exchange (Fig. 2). All values are average $\mathrm{mmol} \mathrm{C} \mathrm{m}^{-2} \mathrm{day}^{-1} \pm \mathrm{SE}$ for the three different phases ( $n=13,8$, and 7 for phases I, II, and III, respectively) in the control mesocosms (M1 + M5) and high$\mathrm{CO}_{2}$ mesocosms (M3 $+\mathrm{M} 8$ ). Solid black arrows indicate measured fluxes. Dashed grey arrows are estimated by closing the budget and indicate the net community production based on inorganic carbon budget $\left(\mathrm{NCP}_{\mathrm{i}}\right)$, which equals biological uptake or release of $\mathrm{CO}_{2}$.

of change in DOC pool (Tables 2 and 3), indicating reduced bacterial uptake and remineralization of DOC. The combined results suggest that the increase in the DOC pool at high $\mathrm{CO}_{2}$ was related to reduced DOC loss (uptake by bacteria), rather than increased release of DOC by the plankton community, at elevated $\mathrm{CO}_{2}$ concentration. 


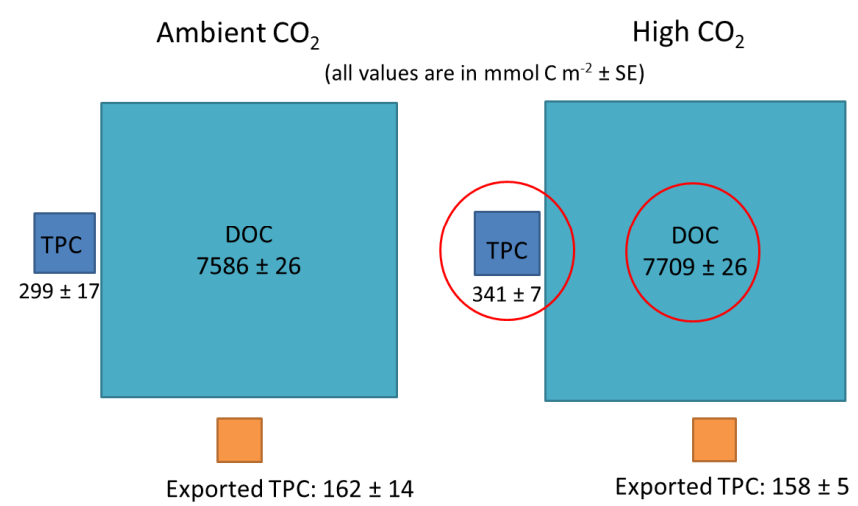

Figure 4. Standing stocks of total particulate carbon (TPC) and dissolved organic carbon (DOC) at the last day of the experiment (t43), plus the sum of exported TPC throughout the experiment; all values are in $\mathrm{mmol} \mathrm{C} \mathrm{m}{ }^{-2} \pm \mathrm{SE}(n=2)$. The values are averages of the two controls (M1 and M5) and the two highest $\mathrm{CO}_{2}$ treatments (M3 and M8). Red circles indicate statistically significant higher standing stocks in the high $\mathrm{CO}_{2}$ treatments (further details in text). The size of the boxes indicates the relative size of the carbon standing stocks and export.

The Baltic Sea is affected by large inflow of freshwater containing high concentrations of refractory DOC, such as humic substances, and the concentration in the Gulf of Finland is typically $400-500 \mu \mathrm{mol} \mathrm{C} \mathrm{L}^{-1}$ (Hoikkala et al., 2015). The large pool of DOC and turnover times of $\sim 200$ days (Tables 1-3) are most likely a reflection of the relatively low fraction of labile DOC, but bacterial limitation of mineral nutrients can also increase turnover times (Thingstad et al., 1997).

The DOC pool has been demonstrated to aggregate into transparent exopolymeric particles (TEPs) under certain circumstances, which can increase sedimentation at high $\mathrm{CO}_{2}$ levels (Riebesell et al., 2007). We did not have any direct measurements of TEP, but any $\mathrm{CO}_{2}$ effect on its formation is highly dependent on the plankton community and its physiological status (MacGilchrist et al., 2014). No observed effect of $\mathrm{CO}_{2}$ treatment on carbon export suggests that we did not have a community where the TEP production was any different between the treatments used.

\subsection{The TPC pool and export of carbon}

There was a positive effect of elevated $\mathrm{CO}_{2}$ on TPC relative to the controls. At the start of the experiment, the measured TPC concentration in the enclosed water columns was 400 $500 \mathrm{mmol} \mathrm{C} \mathrm{m}^{-2}$ (Table 1). The TPC pool decreased over time, albeit less in the high $\mathrm{CO}_{2}$ treatment, and at the end of the experiment the standing stock of TPC was $\sim 6 \%$ higher (phase III, $p=0.01$; Paul et al., 2015) in the high $\mathrm{CO}_{2}$ treatment (Fig. 4).

The export of TPC was not dependent on the $\mathrm{CO}_{2}$ concentration but varied temporally. The largest flux of TPC out of the mesocosms occurred during phase I with $\sim 6 \mathrm{mmol} \mathrm{C} \mathrm{m}^{-2} \mathrm{day}^{-1}$. It decreased to $\sim 3 \mathrm{mmol} \mathrm{C} \mathrm{m}^{-2} \mathrm{day}^{-1}$ during phase II and was $\sim 2 \mathrm{mmol} \mathrm{C} \mathrm{m}^{-2} \mathrm{day}^{-1}$ during phase III (Tables 1-3). The exported carbon as the percent of average TPC standing stock similarly decreased from $\sim 1.3 \%$ during phase I to $0.3-0.5 \%$ during phase III. The initial increase in the autotrophic biomass was likely the reason for relatively more of the carbon settling in the mesocosms in the beginning of the experiment, whereas the decreasing carbon export was most likely caused by the shift towards a plankton community depending on recycled nitrogen. The relatively high initial sedimentation reduced the overall suspended TPC and also the average plankton size in the community.

\subsection{Biological rates: respiration}

TR was always lower in the $\mathrm{CO}_{2}$-enriched treatments (Tables 1-2). The average TR was $83 \mathrm{mmol} \mathrm{C} \mathrm{m}^{-2} \mathrm{day}^{-1}$ during phase I, and initially without any detectable treatment effect. The respiration rate started to be lower in the high $\mathrm{CO}_{2}$ treatments than in the controls in the beginning of phase II. At the end of phase II there was a significant difference $(p=0.02$; Spilling et al., 2016a) between the treatments (Table 2) and $40 \%$ lower respiration rate in the highest $\mathrm{CO}_{2}$ treatment than in the controls (Spilling et al., 2016a).

Cytosol pH is close to neutral in most organisms, and reduced energetic cost for internal $\mathrm{pH}$ regulation (e.g., transport of $\mathrm{H}^{+}$) and at lower external $\mathrm{pH}$ levels could be one factor reducing respiration (Smith and Raven, 1979). Hopkinson et al. (2010) found indirect evidence of decreased respiration and also proposed that increased $\mathrm{CO}_{2}$ concentration (i.e., decreased $\mathrm{pH}$ ) reduced metabolic cost of remaining intracellular homeostasis. Mitochondrial respiration in plant foliage decreases in high- $\mathrm{CO}_{2}$ environments, possibly affected by respiratory enzymes or other metabolic processes (Amthor, 1991; Puhe and Ulrich, 2012). Most inorganic carbon in water is in the form of bicarbonate $\left(\mathrm{HCO}_{3}^{-}\right)$at relevant $\mathrm{pH}$, and many aquatic autotrophs have developed carbonconcentrating mechanisms (CCMs) (e.g., Singh et al., 2014) that could reduce the cost of growth (Raven, 1991). There are some studies that have pointed to savings of metabolic energy due to downregulation of carbon-concentrating mechanisms (Hopkinson et al., 2010) or overall photosynthetic apparatus (Sobrino et al., 2014) in phytoplankton at high $\mathrm{CO}_{2}$ concentrations. Yet other studies of the total plankton community have pointed to no effect or increased respiration at elevated $\mathrm{CO}_{2}$ concentration ( $\mathrm{Li}$ and Gao, 2012; Tanaka et al., 2013), and the metabolic changes behind reduced respiration remain an open question. Membrane transport of $\mathrm{H}^{+}$ is sensitive to changes in external $\mathrm{pH}$, but the physiological impacts of increasing $\mathrm{H}^{+}$need further study to better address effects of ocean acidification (Taylor et al., 2012). An important aspect is also to consider the microenvironment surrounding plankton; exchange of nutrients and gases takes 


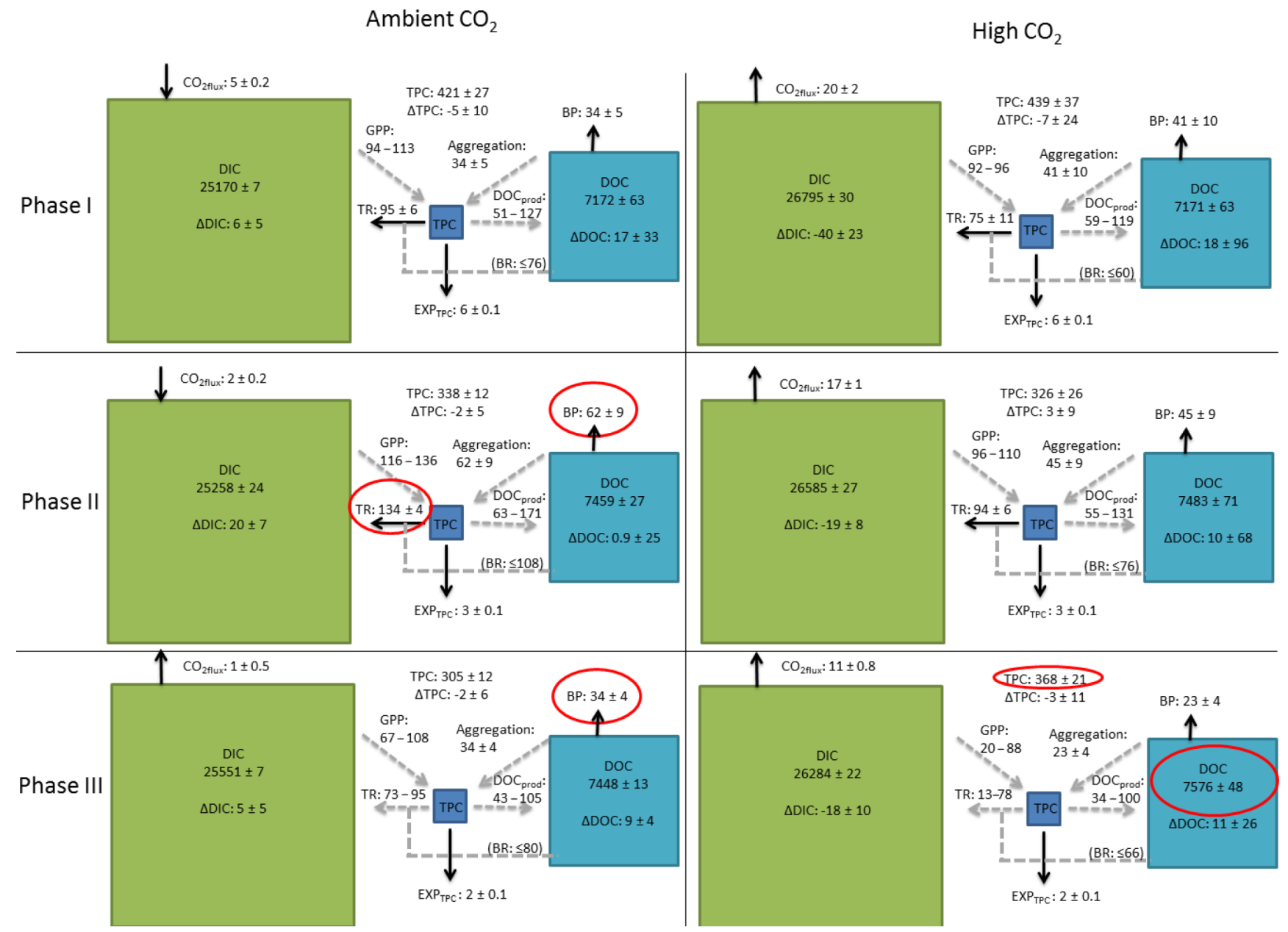

Figure 5. Average carbon standing stocks and flow in the control mesocosms (M1 + M5) and high-CO 2 mesocosms (M3 + M8) during the three phases of the experiment. All carbon stocks (squares) - dissolved inorganic carbon (DIC), total particulate carbon (TPC), and dissolved organic carbon (DOC) - are averages from the start of the period in $\mathrm{mmol} \mathrm{C} \mathrm{m}{ }^{-2} \pm \mathrm{SE}(n=2)$. Fluxes (arrows) and net changes $(\Delta)$ are averages for the whole phase in mmol $\mathrm{C} \mathrm{m}^{-2}$ day ${ }^{-1} \pm \mathrm{SE}$ ( $n$ presented in Table legends $1-3$ ). Solid black arrows indicate measured fluxes (Tables 1-3): TR, BP, and exported TPC (EXP $\mathrm{EPC})$. Dashed grey arrows are estimated by closing the budget: gross primary production

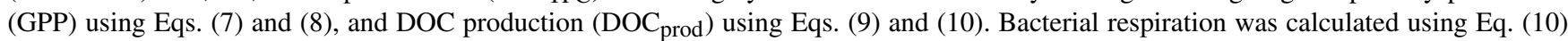
and is a share of TR (indicated by the parenthesis). Aggregation was assumed to equal BP. Red circles indicate statistically significant higher values ( $p<0.05$, tests presented in the primary papers described in Sect. 2.2.). The size of the boxes indicates the relative size of the carbon standing stocks.

place through the boundary layer, which might have very different $\mathrm{pH}$ properties than bulk water measurements (Flynn et al., 2012).

\subsection{Biological rates: bacterial production}

$\mathrm{BP}$ became lower in the high $\mathrm{CO}_{2}$ treatment in the latter part of the experiment. During phase I, BP ranged from 27 to $46 \mathrm{mmol} \mathrm{C} \mathrm{m}^{-2}$ day $^{-1}$ (Table 1). The difference in BP between treatments became apparent in phases II and III of the experiment. The average $\mathrm{BP}$ was 18 and $24 \%$ higher in the controls than in the highest $\mathrm{CO}_{2}$ treatments during phases II and III, respectively (Tables 2 and 3).
The lower bacterial production accounted for $\sim 40 \%$ of the reduced respiration during phase II, and the reduced respiration described above could at least partly be explained by the lower bacterial activity. This raises an interesting question: what was the mechanism behind the reduced bacterial production/respiration in the high $\mathrm{CO}_{2}$ treatment? There are examples of decreased bacterial production (Motegi et al., 2013) and respiration (Teira et al., 2012) at elevated $\mathrm{CO}_{2}$ concentration. However, most previous studies have reported no change (Allgaier et al., 2008) or a higher bacterial production at elevated $\mathrm{CO}_{2}$ concentration (Grossart et al., 2006; Piontek et al., 2010; Endres et al., 2014). The latter was also supported by the recent study of Bunse et al. (2016), de- 
scribing upregulation of bacterial genes related to respiration, membrane transport, and protein metabolism at elevated $\mathrm{CO}_{2}$ concentration; however, this effect was not evident when inorganic nutrients had been added (high Chl $a$ treatment).

In this study, the lower bacterial activity in the high $\mathrm{CO}_{2}$ treatments could either be due to limitation and/or inhibition of bacterial growth or driven by difference in loss processes. Bacterial grazing and viral lysis were higher in the high $\mathrm{CO}_{2}$ treatments during periods of the experiment (Crawfurd et al., 2016) and would at least partly be the reason for the reduced bacterial production at high $\mathrm{CO}_{2}$ concentration.

$\mathrm{N}$ limitation increased during the experiment (Paul et al., 2015), and mineral nutrient limitation of bacteria can lead to accumulation of DOC, i.e., reduced bacterial uptake (Thingstad et al., 1997), similar to our results. Bacterial N limitation is common in the area during summer (Lignell et al., 2013), however, this $\mathrm{N}$ limitation was not apparently different in the controls (Paul et al., 2015), and $\mathrm{CO}_{2}$ did not affect $\mathrm{N}$ fixation (Paul et al., 2016a). In a scenario where the competition for $\mathrm{N}$ is fierce, the balance between bacteria and similar sized picophytoplankton could be tilted in favor of phytoplankton if they gain an advantage by having easier access to carbon, i.e., $\mathrm{CO}_{2}$ (Hornick et al., 2016). We have not found evidence in the literature that bacterial production will be suppressed in the observed $\mathrm{pH}$ range inside the mesocosms, varying from approximately $\mathrm{pH} 8.1$ in the control to $\mathrm{pH} 7.6$ in the highest $f \mathrm{CO}_{2}$ treatment (Paul et al., 2015 ), although enzyme activity seems to be affected even by moderate $\mathrm{pH}$ changes. For example, some studies report on an increase in protein-degrading enzyme leucine aminopeptidase activities at reduced $\mathrm{pH}$ (Grossart et al., 2006; Piontek et al., 2010; Endres et al., 2014), whereas others indicate a reduced activity of this enzyme (Yamada and Suzumura, 2010). A range of other factors affect this enzyme, for example the nitrogen source and salinity (Stepanauskas et al., 1999), and any potential interaction effects with decreasing $\mathrm{pH}$ are not yet resolved. Any $\mathrm{pH}$-induced changes in bacterial enzymatic activity could potentially affect bacterial production.

\subsection{Biological rates: primary production}

There was an effect of $\mathrm{CO}_{2}$ concentration on the net community production based on the organic carbon fraction $\left(\mathrm{NCP}_{\mathrm{o}}\right)$. $\mathrm{NCP}_{\mathrm{o}}$ was higher during phase I than during the rest of the experiments and during this initial phase without any apparent $\mathrm{CO}_{2}$ effect. There was no consistent difference between $\mathrm{CO}_{2}$ treatments for $\mathrm{NPP}_{{ }_{14} \mathrm{C}}(p>0.1)$, but $\mathrm{NCP}_{\mathrm{o}}$ increased with increasing $\mathrm{CO}_{2}$ enrichment during phase II (phase II; linear regression $p=0.003 ; R^{2}=0.91$ ). This was caused by the different development in the TPC and DOC pools. The pattern of GPP was similar to $\mathrm{NCP}_{\mathrm{o}}$ during phases I and II. During phase III there was no respiration or $\mathrm{NPP}_{14} \mathrm{C}$ measurements, and the estimated GPP is more uncertain. The $\mathrm{NCP}_{\mathrm{o}}$ and GPP indicated a smaller difference between treatments during phase III than phase II.
The measures of $\mathrm{NPP}_{14} \mathrm{C}$ and $\mathrm{NCP}_{\mathrm{O}}$ were of a similar magnitude (Tables 1-3). During phase I, $\mathrm{NPP}_{{ }_{14} \mathrm{C}}<\mathrm{NCP}_{\mathrm{o}}$ (Table 1); this relationship reversed for most treatments during phase II, with the exception of the highest $\mathrm{CO}_{2}$ levels (Table 2). The difference between $\mathrm{NPP}_{14} \mathrm{C}$ and $\mathrm{NCP}_{\mathrm{o}}$ suggests that observed reduction in respiration at elevated $\mathrm{CO}_{2}$ could be mainly heterotrophic respiration. However, in terms of the $\mathrm{NPP}_{14}{ }_{14}<\mathrm{NCP}_{\mathrm{o}}$, the uncertainty seems to be higher than the potential signal of heterotrophic respiration. This would also indicate that the $\mathrm{NPP}_{14} \mathrm{C}$ during phase I have been underestimated, in particular for the control mesocosm M1. During phase II, the $\mathrm{NPP}_{14} \mathrm{C}$ was higher than $\mathrm{NCP}_{\mathrm{o}}$, except for the two highest $\mathrm{CO}_{2}$ treatments, more in line with our assumption of $\mathrm{NPP}_{14} \mathrm{C}>\mathrm{NCP}_{\mathrm{o}}$. The systematic offset in $\mathrm{NPP}_{14} \mathrm{C}$ during phase I could be due to changed parameterization during incubation in small volumes ( $8 \mathrm{~mL}$; Spilling et al., 2016a), for example increased loss due to grazing.

The results of the DIC pool and atmospheric exchange of $\mathrm{CO}_{2}$ provide another way of estimating the net community production based on inorganic carbon $\left(\mathrm{NCP}_{\mathrm{i}}\right)$. There was some discrepancy between the $\mathrm{NCP}_{\mathrm{o}}$ and $\mathrm{NCP}_{\mathrm{i}}$ as the latter suggested net heterotrophy in the ambient $\mathrm{CO}_{2}$ treatments, whereas the high $\mathrm{CO}_{2}$ treatments were net autotrophic during all three phases of the experiment (Fig. 3). For the $\mathrm{NCP}_{\mathrm{o}}$ there was no indication of net heterotrophy at ambient $\mathrm{CO}_{2}$ concentration. In terms of the absolute numbers, the $\mathrm{NCP}_{\mathrm{i}}$ estimate is probably more uncertain than $\mathrm{NCP}_{0}$. Calculating the $\mathrm{CO}_{2}$ atmospheric exchange from the measurements of a tracer gas involves several calculation steps (Eq. 1-4), each adding uncertainty to the calculation. However, both estimations $\left(\mathrm{NCP}_{\mathrm{i}}\right.$ and $\left.\mathrm{NCP}_{\mathrm{o}}\right)$ indicate that increased $\mathrm{CO}_{2}$ concentrations lead to higher overall community production, supporting our overall conclusion.

\subsection{Budget}

A carbon budget for the two control mesocosms and two highest $\mathrm{CO}_{2}$ additions is presented in Fig. 5. During phase I the estimated GPP was $\sim 100 \mathrm{mmol} \mathrm{C}$ fixed $\mathrm{m}^{-2} \mathrm{day}^{-1}$, from which $75-95 \%$ was respired, $\sim 1 \%$ ended up in the TPC (including export), and 5-25\% added to the DOC pool. The main difference between $\mathrm{CO}_{2}$ treatments became apparent during phase II when the $\mathrm{NCP}_{\mathrm{o}}$ was higher in the elevated $\mathrm{CO}_{2}$ treatments. The respiration loss increased to $\sim 100 \%$ of GPP at the ambient $\mathrm{CO}_{2}$ concentration, whereas respiration was lower (85-95\% of GPP) in the highest $\mathrm{CO}_{2}$ treatment. Bacterial production was $\sim 30 \%$ lower, on average, at the highest $\mathrm{CO}_{2}$ concentration than in the controls during phase II. The share of $\mathrm{NCP}_{\mathrm{o}}$ of GPP ranged from 2 to $20 \%$, and the minimum flux to the DOC pool was 11 to $18 \%$ of TPC.

The overall budget was calculated by using the direct measurements of changes in standing stocks and fluxes of export, respiration, and bacterial production rates. The most robust data are the direct measurements of carbon standing stocks 
and their development (e.g., $\triangle$ TPC). These are based on well-established analytical methods with relatively low SE of the carbon pools. However, the dynamic nature of these pools made the relative SE for the rate of change much higher, reflecting that the rate of change varied considerably within the different phases.

The rate variables, calculated based on conversion factors, have greater uncertainty, although their SEs were relatively low, caused by uncertainty in the conversion steps. For example, the RQ was set to 1, which is a good estimate for carbohydrate oxidation. For lipids and proteins the RQ is close to 0.7 , but in a natural environment RQ is often $>1$ (Berggren et al., 2012) and is affected by physiological state, e.g., nutrient limitation (Romero-Kutzner et al., 2015). Any temporal variability in the conversion factors would directly change the overall budget calculations, e.g., RQ affecting total respiration and gross primary production estimates. However, the budget provides an order-of-magnitude estimate of the carbon flow within the system. Some of the variables such as GPP were estimated using different approaches, providing a more robust comparison of the different treatments.

The primary effect of increasing $\mathrm{CO}_{2}$ concentration was the higher standing stocks of TPC and DOC compared with ambient $\mathrm{CO}_{2}$ concentration. The increasing DOC pool and relatively higher TPC pool were driven by reduced respiration and bacterial production at elevated $\mathrm{CO}_{2}$ concentration. Decreasing respiration rate reduced the recycling of organic carbon back to the DIC pool. The lower respiration and bacterial production also indicate reduced remineralization of DOC. These two effects caused the higher TPC and DOC pools in the elevated $\mathrm{CO}_{2}$ treatments. The results highlight the importance of looking beyond net changes in carbon standing stocks to understand how carbon fluxes are affected under increasing ocean acidification.

\section{Data availability}

The data presented in this paper can be found in Paul et al. (2016b) and Spilling et al. (2016b).

Acknowledgements. We would like to thank all of the staff at Tvärminne Zoological Station, for great help during this experiment, and Michael Sswat for carrying out the TPC filtrations. We also gratefully acknowledge the captain and crew of R/V ALKOR (AL394 and AL397) for their work transporting, deploying, and recovering the mesocosms. The collaborative mesocosm campaign was funded by BMBF projects BIOACID II (FKZ 03F06550) and SOPRAN phase II (FKZ 03F0611). Additional financial support for this study came from the Academy of Finland (KS - Decisions nos. 259164 and 263862) and Walter and Andrée de Nottbeck Foundation (KS). Thomas Hornick and Hans-Peter Grossart were financially supported by the SAW project TemBi of the Leibniz Foundation. Corina P. D. Brussaard was financially supported by the Darwin project, the Royal Netherlands Institute for Sea Re- search (NIOZ), and the EU project MESOAQUA (grant agreement number 228224).

Edited by: J.-P. Gattuso

Reviewed by: F. Gazeau and one anonymous referee

\section{References}

Allgaier, M., Riebesell, U., Vogt, M., Thyrhaug, R., and Grossart, H.-P.: Coupling of heterotrophic bacteria to phytoplankton bloom development at different $p \mathrm{CO}_{2}$ levels: a mesocosm study, Biogeosciences, 5, 1007-1022, doi:10.5194/bg-5-10072008, 2008.

Amthor, J.: Respiration in a future, higher- $\mathrm{CO}_{2}$ world, Plant Cell Environ., 14, 13-20, 1991.

Badr, E.-S. A., Achterberg, E. P., Tappin, A. D., Hill, S. J., and Braungardt, C. B.: Determination of dissolved organic nitrogen in natural waters using high temperature catalytic oxidation, Trend. Anal. Chem., 22, 819-827, 2003.

Berggren, M., Lapierre, J.-F., and del Giorgio, P. A.: Magnitude and regulation of bacterioplankton respiratory quotient across freshwater environmental gradients, ISME J., 6, 984-993, 2012.

Bermúdez, J. R., Winder, M., Stuhr, A., Almén, A. K., EngströmÖst, J., and Riebesell, U.: Effect of ocean acidification on the structure and fatty acid composition of a natural plankton community in the Baltic Sea, Biogeosciences Discuss., doi:10.5194/bg-2015-669, in review, 2016.

Boxhammer, T., Bach, L. T., Czerny, J., and Riebesell, U.: Technical note: Sampling and processing of mesocosm sediment trap material for quantitative biogeochemical analysis, Biogeosciences, 13, 2849-2858, doi:10.5194/bg-13-2849-2016, 2016.

Brussaard, C. P. D.: Optimization of procedures for counting viruses by flow cytometry, Appl. Environ. Microb., 70, 1506-1513, 2004.

Brussaard, C. P. D., Wilhelm, S. W., Thingstad, F., Weinbauer, M. G., Bratbak, G., Heldal, M., Kimmance, S. A., Middelboe, M., Nagasaki, K., Paul, J. H., Schroeder, D. C., Suttle, C. A., Vaqué, D., and Wommack, K. E.: Global-scale processes with a nanoscale drive: the role of marine viruses, ISME J., 2, 575-578, 2008.

Bunse, C., Lundin, D., Karlsson, C. M., Vila-Costa, M., Palovaara, J., Akram, N., Svensson, L., Holmfeldt, K., González, J. M., Calvo, E., Pelejero, C., Marrasé, C., Dopson, M., Gasol, J. M., and Pinhassi J.: Response of marine bacterioplankton $\mathrm{pH}$ homeostasis gene expression to elevated $\mathrm{CO}_{2}$, Nature Clim. Change, 6, 483-487, 2016.

Crawfurd, K. J., Brussaard, C. P. D., and Riebesell, U.: Shifts in the microbial community in the Baltic Sea with increasing $\mathrm{CO}_{2}$, Biogeosciences Discuss., doi:10.5194/bg-2015-606, in review, 2016.

Czerny, J., Schulz, K. G., Boxhammer, T., Bellerby, R. G. J., Büdenbender, J., Engel, A., Krug, S. A., Ludwig, A., Nachtigall, K., Nondal, G., Niehoff, B., Silyakova, A., and Riebesell, U.: Implications of elevated $\mathrm{CO}_{2}$ on pelagic carbon fluxes in an Arctic mesocosm study - an elemental mass balance approach, Biogeosciences, 10, 3109-3125, doi:10.5194/bg-10-3109-2013, $2013 \mathrm{a}$.

Czerny, J., Schulz, K. G., Ludwig, A., and Riebesell, U.: Technical Note: A simple method for air-sea gas exchange measurements 
in mesocosms and its application in carbon budgeting, Biogeosciences, 10, 1379-1390, doi:10.5194/bg-10-1379-2013, $2013 \mathrm{~b}$.

de Kluijver, A., Soetaert, K., Schulz, K. G., Riebesell, U., Bellerby, R. G. J., and Middelburg, J. J.: Phytoplankton-bacteria coupling under elevated $\mathrm{CO}_{2}$ levels: a stable isotope labelling study, Biogeosciences, 7, 3783-3797, doi:10.5194/bg-7-3783-2010, 2010.

Egge, J. K., Thingstad, T. F., Larsen, A., Engel, A., Wohlers, J., Bellerby, R. G. J., and Riebesell, U.: Primary production during nutrient-induced blooms at elevated $\mathrm{CO}_{2}$ concentrations, Biogeosciences, 6, 877-885, doi:10.5194/bg-6-877-2009, 2009.

Endres, S., Galgani, L., Riebesell, U., Schulz, K.-G., and Engel, A.: Stimulated bacterial growth under elevated $p \mathrm{CO}_{2}$ : results from an off-shore mesocosm study, Plos One, 9, e99228, doi:10.1371/journal.pone.0099228, 2014

Engel, A., Borchard, C., Piontek, J., Schulz, K. G., Riebesell, U., and Bellerby, R.: $\mathrm{CO}_{2}$ increases ${ }^{14} \mathrm{C}$ primary production in an Arctic plankton community, Biogeosciences, 10, 1291-1308, doi:10.5194/bg-10-1291-2013, 2013.

Flynn, K. J., Blackford, J. C., Baird, M. E., Raven, J. A., Clark, D. R., Beardall, J., Brownlee, C., Fabian, H., and Wheeler, G. L.: Changes in $\mathrm{pH}$ at the exterior surface of plankton with ocean acidification, Nature Clim. Change, 2, 510-513, 2012.

Grossart, H.-P., Allgaier, M., Passow, U., and Riebesell, U.: Testing the effect of $\mathrm{CO}_{2}$ concentration on the dynamics of marine heterotrophic bacterioplankton, Limnol. Oceanogr., 51, 1-11, 2006.

Heinänen, A. and Kuparinen, J.: Horizontal variation of bacterioplankton in the Baltic Sea, Appl. Environ. Microb., 57, 3150$3155,1991$.

Hoikkala, L., Kortelainen, P., Soinne, H., and Kuosa, H.: Dissolved organic matter in the Baltic Sea, J. Marine Syst., 142, 47-61, 2015.

Hopkinson, B. M., Xu, Y., Shi, D., McGinn, P. J., and Morel, F. M.: The effect of $\mathrm{CO}_{2}$ on the photosynthetic physiology of phytoplankton in the Gulf of Alaska, Limnol. Oceanogr., 55, 20112024, 2010.

Hornick, T., Bach, L. T., Crawfurd, K. J., Spilling, K., Achterberg, E. P., Woodhouse, J. N., Schultz, K. G., Brussaard, C. P. D., Riebesell, U., and Grossart, H.-P.: Ocean acidification impacts bacteria-phytoplankton coupling at low nutrient-conditions, Biogeosciences Discuss., doi:10.5194/bg-2016-61, in review, 2016.

Jover, L. F., Effler, T. C., Buchan, A., Wilhelm, S. W., and Weitz, J. S.: The elemental composition of virus particles: implications for marine biogeochemical cycles, Nat. Rev. Microbiol., 12, 519528, 2014

Le Quéré, C., Raupach, M. R., Canadell, J. G., Marland, G., Bopp, L., Ciais, P., Conway, T. J., Doney, S. C., Feely, R. A., and Foster, P.: Trends in the sources and sinks of carbon dioxide, Nat. Geosci., 2, 831-836, 2009.

$\mathrm{Li}, \mathrm{W}$. and Gao, K.: A marine secondary producer respires and feeds more in a high $\mathrm{CO}_{2}$ ocean, Mar. Pollut. Bull., 64, 699-703, 2012.

Lignell, R., Hoikkala, L., and Lahtinen, T.: Effects of inorganic nutrients, glucose and solar radiation on bacterial growth and exploitation of dissolved organic carbon and nitrogen in the northern Baltic Sea, Aquat. Microb. Ecol., 51, 209-221, 2008.

Lignell, R., Haario, H., Laine, M., and Thingstad, T. F.: Getting the "right" parameter values for models of the pelagic microbial food web, Limnol. Oceanogr., 58, 301-313, 2013.

Lischka, S., Bach, L. T., Schulz, K.-G., and Riebesell, U.: Microand mesozooplankton community response to increasing $\mathrm{CO}_{2}$ levels in the Baltic Sea: insights from a large-scale mesocosm experiment, Biogeosciences Discuss., 12, 20025-20070, doi:10.5194/bgd-12-20025-2015, 2015.

MacGilchrist, G. A., Shi, T., Tyrrell, T., Richier, S., Moore, C. M., Dumousseaud, C., and Achterberg, E. P.: Effect of enhanced $p \mathrm{CO}_{2}$ levels on the production of dissolved organic carbon and transparent exopolymer particles in short-term bioassay experiments, Biogeosciences, 11, 3695-3706, doi:10.5194/bg-113695-2014, 2014.

Marie, D., Brussaard, C. P. D., Thyrhaug, R., Bratbak, G., and Vaulot, D.: Enumeration of marine viruses in culture and natural samples by flow cytometry, Appl. Environ. Microb., 65, 45-52, 1999.

Menden-Deuer, S. and Lessard, E. J.: Carbon to volume relationships for dinoflagellates, diatoms, and other protist plankton, Limnol. Oceanogr., 45, 569-579, 2000.

Mojica, K. D., Huisman, J., Wilhelm, S. W., and Brussaard, C. P. D.: Latitudinal variation in virus-induced mortality of phytoplankton across the North Atlantic Ocean, ISME J., 10, 500-513, 2016.

Motegi, C., Tanaka, T., Piontek, J., Brussaard, C. P. D., Gattuso, J.P., and Weinbauer, M. G.: Effect of $\mathrm{CO}_{2}$ enrichment on bacterial metabolism in an Arctic fjord, Biogeosciences, 10, 3285-3296, doi:10.5194/bg-10-3285-2013, 2013.

Niiranen, S., Yletyinen, J., Tomczak, M. T., Blenckner, T., Hjerne, O., MacKenzie, B. R., Müller-Karulis, B., Neumann, T., and Meier, H.: Combined effects of global climate change and regional ecosystem drivers on an exploited marine food web, Glob. Change Biol., 19, 3327-3342, 2013.

Olenina, I., Hajdu, S., Edler, L., Andersson, A., Wasmund, N., Busch, S., Göbel, J., Gromisz, S., Huseby, S., Huttunen, M., Jaanus, A., Kokkonen, P., Ledaine, I., and Niemkiewicz, E.: Biovolumes and size-classes of phytoplankton in the Baltic Sea, HELCOM, Balt. Sea Environ. Proc., No. 106, 144 pp., 2006.

Paul, A. J., Bach, L. T., Schulz, K.-G., Boxhammer, T., Czerny, J., Achterberg, E. P., Hellemann, D., Trense, Y., Nausch, M., Sswat, M., and Riebesell, U.: Effect of elevated $\mathrm{CO}_{2}$ on organic matter pools and fluxes in a summer Baltic Sea plankton community, Biogeosciences, 12, 6181-6203, doi:10.5194/bg-12-6181-2015, 2015.

Paul, A. J., Achterberg, E. P., Bach, L. T., Boxhammer, T., Czerny, J., Haunost, M., Schulz, K.-G., Stuhr, A., and Riebesell, U.: No observed effect of ocean acidification on nitrogen biogeochemistry in a summer Baltic Sea plankton community, Biogeosciences, 13, 3901-3913, doi:10.5194/bg-13-3901-2016, 2016 a.

Paul, A., Schulz, K. G., Achterberg, E. P., Hellemann, D., Nausch, M., Boxhammer, T., Bach, L. T., and Trense, Y.: KOSMOS Finland 2012 mesocosm study: carbonate chemistry, particulate and dissolved matter pools, and phytoplankton community composition using marker pigments (CHEMTAX), doi:10.1594/PANGAEA.863032, 2016b.

Piontek, J., Lunau, M., Händel, N., Borchard, C., Wurst, M., and Engel, A.: Acidification increases microbial polysaccharide degradation in the ocean, Biogeosciences, 7, 1615-1624, doi:10.5194/bg-7-1615-2010, 2010.

Puhe, J. and Ulrich, B.: Global climate change and human impacts on forest ecosystems: postglacial development, present situation and future trends in Central Europe, Ecological studies - analysis and synthesis, Springer, Berlin, Germany, 476 pp., 2012. 
Raven, J. A.: Physiology of inorganic $\mathrm{C}$ acquisition and implications for resource use efficiency by marine phytoplankton: relation to increased $\mathrm{CO}_{2}$ and temperature, Plant Cell Environ., 14, 779-794, 1991.

Reynolds, C. S.: Ecology of phytoplankton, Cambridge University Press, Cambridge, UK, 535 pp., 2006.

Riebesell, U., Schulz, K. G., Bellerby, R., Botros, M., Fritsche, P., Meyerhöfer, M., Neill, C., Nondal, G., Oschlies, A., and Wohlers, J.: Enhanced biological carbon consumption in a high $\mathrm{CO}_{2}$ ocean, Nature, 450, 545-548, 2007.

Riebesell, U., Achterberg, E. P., Brussaard, C. P. D., EngströmÖst, J., Gattuso, J.-P., Grossart, H.-P., and Schulz, K. G. (Eds): Effects of rising $\mathrm{CO}_{2}$ on a Baltic Sea plankton community: ecological and biogeochemical impacts, Biogeosciences, http: //www.biogeosciences.net/special_issue204.html, 2015.

Romero-Kutzner, V., Packard, T., Berdalet, E., Roy, S., Gagné, J., and Gómez, M.: Respiration quotient variability: bacterial evidence, Mar. Ecol.-Prog. Ser., 519, 47-59, 2015.

Simon, M. and Azam, F.: Protein content and protein synthesis rates of planktonic marine bacteria, Mar. Ecol.-Prog. Ser., 51, 201213, 1989.

Singh, S. K., Sundaram, S., and Kishor, K.: Photosynthetic microorganisms: Mechanism for carbon concentration, Springer, Berlin, Germany, 131 pp., 2014.

Smith, F. and Raven, J. A.: Intracellular pH and its regulation, Ann. Rev. Plant Physio., 30, 289-311, 1979.

Sobrino, C., Segovia, M., Neale, P., Mercado, J., García-Gómez, C., Kulk, G., Lorenzo, M., Camarena, T., van de Poll, W., Spilling, K., and Ruan, Z.: Effect of $\mathrm{CO}_{2}$, nutrients and light on coastal plankton. IV. Physiological responses, Aquat. Biol., 22, 77-93, 2014.

Spilling, K., Paul, A. J., Virkkala, N., Hastings, T., Lischka, S., Stuhr, A., Bermúdez, R., Czerny, J., Boxhammer, T., Schulz, K. G., Ludwig, A., and Riebesell, U.: Ocean acidification decreases plankton respiration: evidence from a mesocosm experiment, Biogeosciences, 13, 4707-4719, doi:10.5194/bg-13-47072016, 2016a.

Spilling, K., Paul, A., Virkkala, N., Hastings, T., Lischka, S., Stuhr, A., Bermúdez, R., Czerny, J., Boxhammer, T., Schulz, K. G., Ludwig, A., and Riebesell, U.: KOSMOS Finland 2012 mesocosm study: primary production and respiration, doi:10.1594/PANGAEA.863933, 2016b.

Steeman-Nielsen, E.: The use of radioactive carbon for measuring organic production in the sea, J. Cons. Int. Explor. Mer., 18, 117140, 1952.

Stepanauskas, R., Edling, H., and Tranvik, L. J.: Differential dissolved organic nitrogen availability and bacterial aminopeptidase activity in limnic and marine waters, Microb. Ecol., 38, 264-272, 1999.
Steward, G. F., Fandino, L. B., Hollibaugh, J. T., Whitledge, T. E., and Azam, F.: Microbial biomass and viral infections of heterotrophic prokaryotes in the sub-surface layer of the central Arctic Ocean, Deep-Sea Res. Pt. I, 54, 1744-1757, 2007.

Suttle, C. A.: Marine viruses - major players in the global ecosystem, Nat. Rev. Microbiol., 5, 801-812, 2007.

Tamminen, T. and Andersen, T.: Seasonal phytoplankton nutrient limitation patterns as revealed by bioassays over Baltic Sea gradients of salinity and eutrophication, Mar. Ecol.-Prog. Ser., 340, 121-138, 2007.

Tanaka, T., Alliouane, S., Bellerby, R. G. B., Czerny, J., de Kluijver, A., Riebesell, U., Schulz, K. G., Silyakova, A., and Gattuso, J.-P.: Effect of increased $p \mathrm{CO}_{2}$ on the planktonic metabolic balance during a mesocosm experiment in an Arctic fjord, Biogeosciences, 10, 315-325, doi:10.5194/bg-10-315-2013, 2013.

Taylor, A. R., Brownlee, C., and Wheeler, G. L.: Proton channels in algae: reasons to be excited, Trends Plant Sci., 17, 675-684, 2012.

Teira, E., Fernández, A., Álvarez-Salgado, X. A., García-Martín, E. E., Serret, P., and Sobrino, C.: Response of two marine bacterial isolates to high $\mathrm{CO}_{2}$ concentration, Mar. Ecol.-Prog. Ser., 453, 27-36, 2012.

Thingstad, T. F., Hagström, Å., and Rassoulzadegan, F.: Accumulation of degradable DOC in surface waters: Is it caused by a malfunctioning microbialloop?, Limnol. Oceanogr., 42, 398404, 1997.

Veldhuis, M. J. and Kraay, G. W.: Phytoplankton in the subtropical Atlantic Ocean: towards a better assessment of biomass and composition, Deep-Sea Res. Pt. I, 51, 507-530, 2004.

Wanninkhof, R. and Knox, M.: Chemical enhancement of $\mathrm{CO}_{2}$ exchange in natural waters, Limnol. Oceanogr., 41, 689-697, 1996.

Waterbury, J. B., Watson, S. W., Valois, F. W., and Franks, D. G.: Biological and ecological characterization of the marine unicellular cyanobacterium Synechococcus, Can. B. Fish. Aquat. Sci., 214, 71-120, 1986.

Weiss, R. and Price, B.: Nitrous oxide solubility in water and seawater, Mar. Chem., 8, 347-359, 1980.

Wiebe, P. H.: Functional regression equations for zooplankton displacement volume, wet weight, dry weight, and carbon: a correction, Fish. B., 86, 833-835, 1988.

Yamada, N. and Suzumura, M.: Effects of seawater acidification on hydrolytic enzyme activities, J. Oceanogr., 66, 233-241, 2010. 